\title{
APPLYING SIMULTANEOUS ROUNDTABLE TO IMPROVE GENRE-BASED PARAGRAPH WRITING ABILITY
}

\author{
I KomangBudiarta \\ English Language Education Study Program, Faculty of Teacher Training and Education \\ Mahasaraswati Denpasar University \\ email:mrbudi@live.com
}

\begin{abstract}
ABSTRAK
Untuk menulis paragraph yang menarik, mahasiswa harus rajin melatih keterampilan menulisnya. Akan tetapi, fakta menunjukkan bahwa keterampilan menulis adalah keterampilan yang menakutkan dan membosankan untuk dipelajari karena dosen menerapkan teknik mengajar yang membosankan dan monoton. Oleh karena itu, penelitian ini dilaksanakan untuk menjawab rumusan masalah: bagaimana efektivitas simultaneous roundtable untuk meningkatkan kemampuan mahasiswa dalam menulis genre-based paragraph? dan bagaimana mahasiswa merespon penerapan simultaneous roundtable dalam pengajaran menulis genre-based paragraph. Subjek penelitian ini adalah dua kelas dari mahasiswa semester kedua Program Studi Pendidikan Bahasa Inggris, Fakultas Keguruan dan Ilmu Pendidikan Universitas Mahasaraswati Denpasar yang berjumlah 62 orang mahasiswa. Desain penelitian ini adalah penelitian tindakan kelas yang dilaksanakan dalam tiga siklus. Peningkatan hasil dari pre-tes, post-tes 1, 2, dan 3 menunjukkan bahwa simultaneous roundtable sangat efektif dalam meningkatkan kemampuan menulis genre-based paragraph. Di samping itu, hasil dari kuesioner menunjukkan bahwa sebagian besar subjek penelitian setuju dengan penerapan simultaneous roundtable dalam pengajaran menulis genre-based paragraph
\end{abstract}

Kata kunci: simultaneousroundtable, keterampilanmenulis, dangenre-based paragraph.

\section{ABSTRACT}

To write an 'attention grabbing' paragraph, the students should do a lot of practices in writing. However, the fact showed that writing skill was frightening and boring skill to learn as lecturers applied boring and monotonous teaching technique. Thus, the present research was mainly intended to answer the following questions: how effective is simultaneous roundtable in improving the students' genre-based paragraph writing ability? and how do the students respond the application of simultaneous roundtable in teaching genre-based paragraph writing? The subjects of this research were two classes of the second semester students of English Education Study Program Faculty of Teacher Training and Education Mahasaraswati Denpasar University which consisted of 62 students altogether. The design of the present study was classroom action research which were carried out in three cycles. The progressing results of the pre-test, post-test 1, 2 and 3 confirmed that simultaneous roundtable was effective in improving genre-based paragraph writing ability. In addition, the results of the questionnaire showed that most of the subjects agreed on the application of simultaneous roundtable in teaching genre-based paragraph writing.

Keywords: simultaneous roundtable, writing skill, and genre-based paragraph. 


\section{INTRODUCTION}

Writing skill as one of the most important language skills enables students to express their ideas in a 'controllable' way. Since it is controllable, they are able to control their ideas and other language features.It is therefore useful to minimize the mistakes before it is published. It is in line with Jones (2007) who states that students can pause after each word while they think of the next word they want to write.Furthermore, the students can imaginatively and creatively produce their ideas as they have the opportunity to think and re-think the ideas to make them more interesting. Being involved in writing activities also enables them to develop their creativity in using the language especially in the written form.

Writing providesthe lecturers so many aspects that should be taken into account.In addition, they should consider those aspects both in teaching and assessing the students' writing ability. Both teaching and assessing writing are challenging for lecturers. Brown (2004) furthermore mentions that writing skill, which is categorized as productive skill, should be taught and assessed in different ways with receptive skills.As writing is an active skill, the lecturers should actively involve the students in the classroom activity. This learning atmosphere facilitates the students to produce the language that they have already studied in the classroom. Writing is a productive skill which takes a long and complicated process; consequently, it is of necessary for the lecturers to provide plenty rooms of practices.

Brown (2001) also clarifies that there are some aspects of teaching writing that need to be considered in teaching writing: lecturers' focus, authenticity, and lecturers' roles. The lecturers should focus not only on the writing product but also process so that the students will produce more authentic pieces of writing. In writing process, the lecturers should be able to become facilitators and coaches. Furthermore, Harmer (2004) states that teaching writing should not be carried out as a linear process; it should be recursive. It means that in teaching writing the lecturers should expose the students with activities in which writing is not only a process that is started by planning, drafting, editing and final draft but also a process in which the students often re-plan, re-draft, and re-edit.

In accordance with the processes that are needed in teaching writing, Nunan (2003) suggests some principles to teaching writing; they are understanding the students' reasons for writing, providing many opportunities for them to write, making feedback helpful and meaningful, and clarifying for the lecturers andthe students, how their writing is evaluated. These principles clearly guide the lecturers about what they should do in the teaching learning process of writing so that the skill can be significantly improved. In other words, as writing skill emphasizes on the process; therefore, it is not an instant skill which can be achieved or mastered in a fingers-snap; writing is challenging to be taught. It is also a long and complicated process.

In addition, Oshima\& Hogue (2007) clearly mention that there are five criteria that should be taken into account in writing a good paragraph. They are format, punctuation and mechanics, content, organization and grammar and sentence structure. These criteria are important since 
they can be used as guidance to write a paragraph which is interesting for the readers to read. Fulfilling the criteria of writing a paragraph also affects the process of scoring the paragraph; as it is productive, the product should be scored by using scoring rubric which can create more objective scores. An objective scoring is very important in writing because students will feel that their writing is well and carefully checked.

Writing is challenging to be improved in teaching learning process. It happens because a lot of lecturers are still difficult to improve the students' paragraph writing ability. A lot of university students consider writing as a boring skill which results in unwillingness to improve their writing ability. In addition, according to the lecturers, teaching writing is challenging as it needs various teaching techniques and continuous modification of teaching materials. They have already implemented different teaching techniques in teaching learning process; however, it fails again and again. Classroom management of writing is also one of their difficulties to create more qualified and enjoyable teaching learning process.

In assessing the students' paragraph writing, the lecturers also sometimes do not apply an appropriate scoring which makes them feel that their writing is not objectively scored. It also causes the students apathetic and they are unwilling to improve their writing ability. Therefore, the lecturers should try to use more objective scoring rubric which can give more dependable scores towards the students' writing. Besides, the lecturers can adapt an available scoring rubric. The use of scoring rubric can assist the lecturers in order to create more objective scoring procedure. There are some available choices of scoring rubric which can be simply adapted for the sake of carrying out an objective scoring process.

In teaching learning process of Paragraph Writing Coursein English Education Study Program, Faculty of Teacher Training and Education, Mahasaraswati Denpasar University, it was found that the teaching learning process was not really optimal. The second semester students felt boring because the technique was quite monotonous and they were still difficult to express their ideas in writing especially genre-based paragraphs, such as descriptive, recount and narrative.It happened because of the inability of the lecturers to vary their teaching learning process in order to create different classroom atmosphere. The inability of the lecturers to vary their teaching occurred because some of them had a limited stock of teaching techniques. The others are confused in deciding which technique was mostly effective in teaching writing since there are so many available teaching techniques which can be readily implemented.

The present research applied one of the techniques in cooperative learning method, Simultaneous Roundtable. It is in line with Harmer (2007:328) who also clearly adds that "writing is a cooperative activity." Thus, the researcher was interested to improve the students' genrebased paragraph writing ability by applying simultaneous roundtable. Empirically, Wang (2009) who did a study on applying cooperative learning models to teach conversational skills showed that their conversational skills including writing 
skills improved significantly and they were motivated through the group work in the cooperative learning. It proved that cooperative learning might give different learning atmosphere which made the students enjoy practicing their writing.

In the present study, simultaneous roundtable was carried out based Kagan and Kagan (2009). First of all, the lecturer gave the students a topic to be developed into a genre-based paragraph. Second, each student in the group ofthree to four students wrote a genre-based paragraph while sitting in a roundtable.Third, the lecturer asked all of the students in one group to work individually by writing down the paragraph on their own piece of paper.After the students have finished writing the paragraph, the lecturer asked the students in the group to rotate the paper clockwise based on the time signal.Each member of the group should try to check and revise parts of the paragraph that they think incorrect.

In line with the background which has been previously elaborated, the present research was limited on applying simultaneous roundtable to improve the students' genre-based paragraph writing ability. Furthermore, this research was intended to answer the research problems which have been previously formulated. The research problems were as follows: how effective is simultaneous roundtable in improving the students' genre-based paragraph writing ability? and how do the students respond the application of simultaneous roundtable in teaching genrebased paragraph writing?

The present research was carried out to figure out the scientific answers of the research problems. Stating the clear and reachable purpose of scientific research was important to direct the research and to give scientific map in carrying out the research. Generally, the purpose of the present study was to know the effectiveness of simultaneous roundtable in improving the students' genre-based paragraph writing. Besides the general purpose, the specific purposes of the present study were to figure out: the effectiveness of simultaneous roundtable in improving the students' genre-based paragraph writing ability and the responses of the students towards the application of simultaneous roundtable in teaching genre-based paragraph writing.

\section{RESEARCH METHOD}

The design of the present research made use of Classroom Action Research. This research was carried out in some cycles of cyclical processes. The cyclical processeswere initially started by conducting a preliminary observation. It was intended to figure out the pre-existing problem faced by the subjects of the present research. In addition, each cycle of the classroom action research consisted of four interconnected activities. They were planning, action, observation and reflection.Based on the result of the reflection in the previous cycle, the researcher evaluated the weaknesses of the cycle and they were then used to revise the next planning. The cyclical processes were carried out until it achieved the purpose of conducting the present classroom action research that was all of the subjects achieved the minimum passing grade which had been determined, 70 .

Based on the results of the preliminary observation, the subjects of the 
present classroom action research were the second semester students of English Education Study Program, Faculty of Teacher Training and Education, Mahasaraswati Denpasar University. The classes that were specifically chosen as the subjects of the research were the second semester of A and B class; there were respectively 32 and 30 students altogether. They were chosen as the subjects because they had difficulty in expressing their ideas in written forms. They found difficulty in starting their ideas at the very beginning of their paragraph. Besides, a lot of them were unable to write the paragraph by using generic structures which were appropriate based on the genre-based paragraph.

In the present classroom action research, the researcher made use of two research instruments; they were test and questionnaire. The test was divided into two, pre-test and post-test. Both of the tests were constructed in the form of paragraph construction test. The subjects were asked to write a genre-based paragraph based on the provided topics. The subjects' paragraphs were carefully scored by using an analytical scoring rubric which had five criteria: format, punctuation and mechanics, content, organization, and grammar and sentence structure. In addition, to quantify the subjects' responses on the implementation of the technique, the researcher administered a questionnaire which consisted of ten items. The questionnaire was in the form of structured questionnaire which had five choices: strongly agree, agree, undecided, disagree and strongly disagree.

\section{FINDING AND DISCUSSION Finding}

The present classroom action research was carried out in cyclical processes. It was started by carrying out a preliminary observation at the very beginning of the research. It was intended to figure out the pre-existing difficulty of the subjects in writing. In the present research, there were three cycles which were conducted to achieve the success indicator that was all of the subjects achieved the minimum passing grade, 70 . Each cycle which was carried out was conducted based on the four interconnected activities; they were planning, action, observation and reflection. The findings which were collected and analyzed in precycle, cycle I, II and III can be descriptively presented as follows.

\section{Pre-cycle}

As what has been aforementioned, the present classroom action research was initially started by conducting a preliminary observation in which the researcher observed the subjects of the study, the second semester students of A and B class. The researcher observed the subjects during the teaching learning process of writing. Moreover, the researcher administered a pre-test to get more comprehensive data on the subjects' weaknesses in genre-based paragraph writing ability.

In the present research, a pre-test was constructed to collect the data which quantified the subjects' pre-existing ability in writing genre-based paragraph. The subjects were required to choose a topic among some topics provided and the topic that was chosen was developed into a genre-based paragraph based on their initial 
knowledge on the genre paragraph itself. The pre-test was followed by 62 subjects altogether. Based on the results of the pretest, it was found that the minimum and maximum scores were respectively 35 and 65. Besides, the mean score was 50.32; it was categorized as sufficient. The results also showed that none of the subjects achieved the minimum passing grade that was 70.

In accordance with the results of the pre-test, most of the subjects chose descriptive paragraph topic to be developed into a paragraph and a few of them selected recount and narrative topics. Their writing clearly showed that they still needed more guidance and practices. Most of the subjects were unable to write the paragraph which had complete generic structures. Furthermore, they could not write the paragraph which fulfilled the necessary characteristics of good paragraph, unity and coherence. They were also confused in using the language features in different genre paragraph. These results confirmed that their genre-based paragraph writing ability needed to be improved. Therefore, the researcher started cycle $I$ and implemented simultaneous roundtable.

\section{Cycle I}

Cycle I was carried out based on the results in the pre-cycle especially pre-test. This cycle consisted of two sessions of teaching. As what has been previously mentioned, this cycle was comprised by four interconnected activities. They were planning, action, observation and reflection. In this cycle, simultaneous roundtable was procedurally applied to improve the subjects' ability in writing genre-based paragraph. The interconnected activities of cycle I was elaborated as follows.

In planning of cycle I, the researcher prepared what were needed in implementing the research. The researcher prepared lesson plan, learning material, worksheet and post-test. The lesson plan was constructed for two sessions in which each session consisted of 90 minutes. The learning material that was prepared was about 'Descriptive Paragraph'. To provide the subjects opportunity to practice writing the descriptive paragraph, worksheet was prepared. Post-test was also constructed to measure the subjects' progress on genrebased paragraph writing ability after the implementation of the technique. Moreover, the researcher designedinteresting presentation to attract the subjects in teaching learning process.

After the planning has been well prepared, it was continued to the next stage that was action. In action, what has been planned was put into practice. In this stage simultaneous roundtable was applied in teaching learning process of both sessions. The learning material and worksheet were delivered to improve the subjects' writing ability. In this stage, the researcher did not only become a lecturer but also an observer. In the observation, the researcher found that the subjects were still difficult in accepting the technique and they were unwilling to do discussion with their friends. Besides, it seemed that they found difficulty in understanding the learning material.

After two sessions of teaching, the researcher then administered post-test 1 that has been constructed. It was mainly intended to measure the subjects' progress in writing genre-based paragraph after the 
implementation of simultaneous roundtable. In the post-test, the subjects had to choose, 'My Favorite Teacher/Lecturer' or 'My Favorite Possession' to be developed into a descriptive paragraph. The post-test which was followed by 62 subjects altogether showed that the minimum score was 60 and the maximum score was 86 . The mean score was 71.55 which was categorized as good. Based on the result of the post-test, it was counted that there were 36 subjects who could achieve the minimum passing grade. Since the improvement was not yet optimal, the researcher then continued to cycle II.

\section{Cycle II}

Based on the results of post-test 1, the researcher continued the research to the next cycle, cycle II. This cycle was approximately similar with the previous cycle. Cycle II also consisted of four interconnected activities. They were planning, action, observation and reflection. This cycle was expected to yield much better results than cycle I. Therefore, this cycle was started by revising the planning. In this cycle, simultaneous roundtable was also applied systematically based on the theory.

The planning in cycle II was revised based on the weaknesses in cycle I. In this cycle, the researcher prepared more interactive material and more competitive application of simultaneous roundtable. In planning of cycle II, the researcher also prepared lesson plan, learning material, worksheet and post-test. The lesson plan for cycle II was allotted for two meetings which spent 180 minutes. The learning material that was delivered in cycle II was about 'Recount Paragraph'. They were taught about generic structure, social function and the writing process of recount paragraph. The worksheet was also prepared to give the subjects more practices in writing recount paragraph. Finally, posttest was constructed to measure the subjects' progressing achievement in writing genre-based paragraph in this cycle.

Action as the important stage was the next activity that was carried out to collect the data. What has been planned in the previous stage was carefully applied. To attract the subjects' attention, the learning materials were presented more attractively so that they put their attention on the process of listening. In this stage, the researcher also applied simultaneous roundtable by emphasizing on the role of every member in the group. The technique was procedurally implemented to achieve a better result. The researcher also observed the subjects during the teaching learning process. Based on the observation, the subjects were getting used to the implementation of the technique. Moreover, they were more motivated to get involved in the discussion.

At the end of the teaching learning process, the researcher administered posttest 2 to the subjects under study. They were required to write a recount paragraph based on the provided topics, 'A Visit to ...' or 'My Friend's Vacation'. They should write 6-12 sentences paragraph which fulfilled the characteristics of a good paragraph based on the scoring rubric. Post-test 2 which was followed by all of the subjects in the present classroom action research yielded a mean figure of 79.16. The mean score was categorized as good and the subjects who obtained the minimum passing grade increased. There 
were 58 subjects who successfully achieved the minimum passing grade. In this cycle, there were a few subjects who still got 65 even though there was a subject who could attain 92 as the maximum score. As the result was not yet significant, the researcher conducted cycle III.

\section{Cycle III}

The results of cycle II showed that there was significant improvement from pre-test to post-test 1 and 2.However, the success indicator that was all subjects could achieve the minimum passing grade was not yet achieved. Thus, the researcher did revision on the planning of cycle III based on the results of cycle II. This cycle was also followed by the other stages: action, observation and reflection. The interconnected activities that were carried out in cycle III were described as follows.

The researcher believed that planning should be well prepared if the objective was to conduct more effective and efficient action. Thus, the researcher planned everything which was needed for the action. The planning was not really different with cycle II; there were lesson plan, learning material, worksheet, post-test and questionnaire. The time allotment of the teaching learning process in cycle III was also 180 minutes for two sessions and the learning material was about 'Narrative Paragraph'. The subjects were also provided with some topics to practice their writing ability in narrative paragraph. Posttest 3 was also created to figure out the subjects' improvement of genre-based writing ability. To quantify the subjects' responses on the implementation of simultaneous roundtable, the researcher also constructed a structured questionnaire.
Cycle III was expected to achieve the success indicator; the researcher therefore conducted the action more attentively based on the weaknesses in the previous cycle. In the action, the researcher focused on some parts that still became problem for the subjects. More emphasis was given on the process of delivering the learning material. In addition, simultaneous roundtable was implemented and it was intended to attract the subjects' attention and to actively involve on the learning process. During the observation, the researcher saw that the subjects became more attentive and active during the teaching learning process especially on the implementation of the technique. It seemed that the subjects were more motivated and interested in following the teaching learning process of paragraph writing through the application of simultaneous roundtable.

Finally, to measure the subjects' progressing improvement of genre-based paragraph writing ability, the researcher gave post-test 3 to the subjects. They were asked to write a narrative paragraph which consisted of 6-12 sentences by choosing one of the topics, 'The Bad Day on the Birthday' or 'My Terrible Vacation'. The results of their paragraphs were also scored by using scoring rubric which had five criteria: format, punctuation and mechanics, content, organization, and grammar and sentence structure. Based on the obtained total score, the researcher then calculated the mean score. The mean score was a figure of 83.10; it was categorized as good. Furthermore, all of the subjects could achieve the minimum passing grade in this cycle because the minimum and maximum scores were 70 and 91 respectively. Since 
the success indicator had been achieved, the researcher then stopped the research and administered the questionnaire.

\section{The Response of the Questionnaire}

The present classroom action research was also intended to quantify the subjects' responses on the implementation of the technique. Thus, the researcher administered a questionnaire to the subjects. The questionnaire was constructed in the form of structured questionnaire on the basis of Likert rating scale 1-5. It consisted of five alternative choices; strongly agree, agree, undecided, disagree and strongly disagree and it had ten items. The data that were collected by using the questionnaire were analyzed in the form of percentages and they were then descriptively presented.

Based on the tabulation of the questionnaire, it was found that there were $53.96 \%$ of the responses which showed that the subjects responded strongly agree on the application of simultaneous roundtable in teaching genre-based paragraph writing; $40.37 \%$ of the responses, agree; $5.30 \%$ of the responses, undecided; $0.37 \%$ of the responses, disagree and none of the subjects responded strongly disagree. The result of the questionnaire clearly showed that the subjects' responses were positive towards the implementation of simultaneous roundtable in teaching genrebased paragraph writing. It can be seen that there were more than $94 \%$ of the responses which showed that the subjects positively agreed on the application of simultaneous roundtable to improve their genre-based paragraph writing ability.

\section{Discussion \\ The Progressing Improvements of Genre- based Paragraph Writing Ability}

The present classroom action research was carried out in three cycles and it was preceded by conducting a preliminary observation before the cyclical processes were applied. The second semester students of $\mathrm{A}$ and $\mathrm{B}$ class which consisted of 62 students altogether were chosen as the subjects of the study. To answer the previously formulated research problems especially on the effectiveness of simultaneous roundtable, the data were then collected from the subjects by using tests in pre-cycle, cycle I, II and III.

The results of the preliminary observation especially the pre-test clearly showed that the mean score was a figure of 50.32. It was categorized as sufficient and there were none of the subjects who could achieve the minimum passing grade. The subjects had difficulty in organizing their ideas into a good paragraph which was unified and coherent. Their paragraphs were also incomplete in terms of generic structure because some of them missed one of the generic structures. The subjects were also difficult to control during the teaching learning process and it seemed that they looked bored during the teaching learning process. It might happen because the lecturers applied the same teaching technique all the time.This also made the subjects think that writing was difficult. Based on this results, the researcher then conducted cycle I by applyingsimultaneous roundtable.

Cycle I was carried out through four interconnected activities. The mean score of cycle I was 71.55; it was categorized as good. In this cycle, there were 36 subjects 
who could obtain the minimum passing grade. Based on the results of their paragraphs which were scored by using a scoring rubric, it was found that in terms of format, some of the subjects still wrote the descriptive paragraph inappropriately. The first sentence was not indented and they did not put margin on both sides. The uses of punctuation and mechanics were acceptable but a little bit monotonous. They have already written the descriptive paragraph which had complete generic structure. However, the ideas that they expressed in the written forms were not arranged in unity and coherence. They were still confused in writing a paragraph which was unified and coherent. Their grammatical features also still became their additional problem in writing.

The second cycle was signified by the improvement of the mean score that was 79.16 (i.e. it was categorized as good). It was also followed by the significant increase in terms of the number of the subjects who could achieve the minimum passing grade. In cycle II, there were 58 subjects who obtained the minimum passing grade. The results of post-test 2 clearly showed that the subjects could write a recount paragraph based on the appropriate format of scoring rubric. The paragraph was indented and there were margins on both sides. The uses of punctuation and mechanics in their paragraph were getting varied. Moreover, their paragraphs were also complete in terms generic structure even though a few parts were inappropriately written. The quality of their unified and coherent ideas were getting better. They could arrange their ideas based on the provided topics and some of them could develop an interesting recount paragraph even though grammatical features still became their problem in expressing the ideas in written forms.

Finally, cycle III was the last cycle of the present classroom action research. Based on the data analysis, the mean score was a figure of 83.10 which was categorized as good. In this cycle, all of the subjects achieved the minimum passing grade, 70 . In line with the mean score, the quality of their paragraph was getting better. Based on the scoring rubric which consisted of five criteria: format, punctuation and mechanics, content, organization, and grammar and sentence structure. A few of them still faced problem in organizing their ideas by using correct usage of grammatical features. It can be summed up that from cycle to cycle the active involvement of the subjects in teaching genre-based paragraph by applying simultaneous roundtable was getting better. They enjoyed the learning process of genre-based paragraph writing.The results of their paragraph also confirmed that there were significant improvements from cycle to cycle. Since the success indicator could be successfully achieved, the present classroom action research was ended in cycle III.

\section{The Responses towards the Application of Simultaneous Roundtable}

In the present classroom action research, the researcher was interested to quantitatively figure out the subjects' responses on the implementation of simultaneous roundtable in teaching genrebased paragraph writing. Thus, the structured questionnaire was administered to the subjects. Based on the results of the 
questionnaire analysis in the forms of percentages, it was found that more than $94 \%$ of the responses showed that the subjects agreed on the implementation of the technique in improving their genrebased paragraph writing ability. In addition, there were only $0.37 \%$ of the responses that the subjects disagreed on the implementation of the technique. In general, most of the subjects warmly accepted simultaneous roundtable as an appropriate technique in teaching genrebased paragraph.

Based on the results of their questionnaire, they were motivated by the implementation of simultaneous roundtable. It happened because in cycle II and III, the researcher competed the groups so that the competitive sense improved their motivation to get better in the teaching learning process. They also mentioned that the application of this technique enabled them to have more practices in writing genre-based paragraph. This was really helpful to make their paragraph much better because they felt that they were wellguided.Furthermore, they could work as a team to complete the assigned task during the writing practices. They were getting used to take part and be responsible on their part. The application of simultaneous roundtable also improved their creativity in writing genre-based paragraphs. They could write their paragraphs much more interesting and they have used different styles of writing in order to make it more attractive.

In addition, the implementation of simultaneous roundtable affected not only their ability but also their self-confidence in expressing the ideas in written forms. Previously, when they wanted to write a paragraph, they were confused what should be written and they were difficult to write the first sentence of their paragraph. After the implementation of simultaneous roundtable, their self-confidence improved because they had a lot of rooms for practices. They also stated that the application of simultaneous roundtable guided them well in writing genre-based paragraphs especially in organizing unified and coherent ideas. Besides, they could develop their ideas in writing a genre-based paragraph which had complete generic structure. It happened because this technique concerned on the process of writing. To sum up, the implementation of simultaneous roundtable has changed their paradigm that writing was difficult and boring into easy and enjoyable.

\section{CONCLUSION}

The present classroom action research was conducted thoroughly in three cycles. It was ended at cycle III because the success indicator has been achieved. Based on the results of the tests, pre-test and posttests, there were significant improvements of the subjects mean score from pre-cycle to cycle III. The mean scores progressively improved from the results of pre-test and post-test 3 . In addition, the number of the subjects who could achieve the minimum passing grade also increased significantly and in cycle III all of the subjects achieved the minimum passing grade. This results clearly confirmed that simultaneous roundtable was effective in improving genre-based paragraph writing ability of the second semester students.

In addition, based on the results of the questionnaire which were analyzed on the basis of response percentages, it was 
figured out that more than $94 \%$ of the responses showed that the subjects agreed towards the implementation of simultaneous roundtable in improving genre-based paragraph writing. They felt that they enjoyed the application of the technique in teaching learning process of genre-based paragraph writing. To summarize, the second semester students responded the application of simultaneous roundtable positively.

\section{REFERENCES}

Arends, R. I. (2007). Learning to Teach (Seventh Edition). New York: the McGraw-Hill Companies.

Brown, H. D. (2001). Teaching by Principles: An Interactive Approach to Language Pedagogy (Second Edition). New York: Pearson Education.

Brown, H. D. (2004). Language Assessment: Principles and Classroom Practices. White Plains, New York: Pearson Education.

Jones, L. (2007). The Student-Centered Classroom. New York: Cambridge University Press.

Harmer, J. (2004). How to Teach Writing. Edinburgh: Pearson Education Limited.

Kagan, S. and Kagan, M. (2009). Kagan Cooperative Learning. San Clemente: Kagan Publishing.

Nunan, D. (2003). Practical English Language Teaching. New York: the McGraw-Hill Companies.

Oshima, A. \& Hogue, A. (2007). Introduction to Academic Writing (Third Edition). White Plains, NY: Pearson Education.

Richards, J. C. \& Rodgers, T. S. (2001). Approaches and Methods in Language Teaching (Second Edition). New York: Cambridge University Press.
Wang, T. P. (2009). Applying Slavin's Cooperative Learning Techniques to a College EFL Conversation Class, The Journal of Human Resources and Adult Learning, 5(1), 112-122.

Zemach, D. E. \&Rumisek, L. A. (2005). Academic Writing from Paragraph to Essay. Oxford: Macmillan Education. 